\title{
Successful privatization of state property: factors and their impact on efficiency
}

\author{
Mikhail Khamidulin ${ }^{1,2}$, Dilfuza Rakhimova ${ }^{1}$, Shakhlo Abdullaeva ${ }^{2}$, Muyassarhon Ganieva ${ }^{3}$, \\ and Bahramjon Mamatov ${ }^{1}$ \\ ${ }^{1}$ Academy of Public Administration under the President of the Republic of Uzbekistan, st. Karimov \\ 45, 100066 Tashkent, Uzbekistan \\ ${ }^{2}$ Tashkent branch of the Russian University of Economics. G.V. Plekhanov, st. Shahriobod, 3, 100164 \\ Tashkent, Uzbekistan \\ ${ }^{3}$ Tashkent State University of Economics, st. Karimov 49, 100066 Tashkent, Uzbekistan
}

\begin{abstract}
Successful privatization of state property depends on the investment attractiveness of the objects being sold, as well as the general investment climate of the country and the level of development of the financial infrastructure. In the Republic of Uzbekistan, with the adoption of the Decree of the President of Uzbekistan dated October 27, 2020. № UP6096 "On measures to accelerate the reform of enterprises with the participation of the state and the privatization of state assets", a new stage of privatization of state property began. A significant place in the privatization program is given to the restructuring of state property, improving the efficiency of managing state assets and bringing shares of Uzbek issuers to the world capital markets (IPO). The article examines the degree of influence of an effective corporate governance system and the level of capitalization of the national securities market, contributing to an increase in investment attractiveness and the most effective practical manifestation of the generic advantages of a joint-stock company, ensuring the achievement of the main goal of corporatization - attracting direct investment.
\end{abstract}

\section{Introduction}

The formation of a market economy, the effectiveness of which in the socio-economic development of society has been proved by the experience of the world development of mankind, is not possible without the creation of a multi-structured economy, the basis of which is the competitive competition of various forms of ownership. Denationalization and privatization laid the foundation and became a catalyst for the formation and development of the national stock market, the development and application of mechanisms for effective practical implementation of internationally recognized principles of corporate governance of the OECD [1]. With regret, it must be admitted that over the past years, despite the ongoing work to transform state property, no more than 10-15 percent have actually been privatized, mainly in the field of consumer services, trade, local industry, public catering, housing and communal services, etc. P. The enterprises of the basic sectors of the economy of Uzbekistan are de facto, almost $100 \%$, still owned by the state. A new stage of 
privatization of state property in the Republic of Uzbekistan, the main target parameters for the implementation of which were laid down by the Decree of the President of the country dated 10.27. № UP-6096 "On measures for accelerated reform of enterprises with state participation and privatization of state assets", which provides for the introduction of transparent and market-based principles in the basic industries, "... creation of broader opportunities for participation in the reform process of private capital, reduction of state participation in the economy and further improvement of the competitive environment "[2].Despite the detailed privatization program approved by the aforementioned decree, certain doubts arise that further attempts to form truly market-based property relations in the republic's economic sector may again turn out to be ineffective, primarily in terms of attracting direct investment in privatization objects.At the same time, despite the presence of a formal infrastructure that ensures the attraction of investors to privatization objects through their transformation into joint-stock companies and the sale of issued shares, in the domestic scientific community there is a lack of theoretical developments that reveal the essential characteristics of a joint-stock company, allowing full use of the generic advantages of corporate forms of management in attracting direct, long-term, financial investments. As a result, the adopted practical management decisions do not consider the investment attractiveness of joint-stock companies in the relationship and interdependence of the applied corporate governance system with the level of development of the securities market, especially its secondary segment.

\section{Materials and methods}

Conceptual foundations in the formation and development of economic science on corporate governance were introduced by leading foreign economists: A. Burleigh, G. Means, B. Black, R. Kreckman, E. Rosenbaum. The theory of corporate finance management was developed in the scientific works of M. Miller, F. Modigliani, M. Gordon, D. Lintner, R. Litzenberger, R. Brailey, S. Myers. Standard neoclassical schemes of a firm's behavior in various environments and organizational features of a corporation are investigated in the works of S. Fischer, R. Dornbusch, R. Schmalenzi, R. Pindike, D. Rabinfeld, R. Friedman, A. Rapensky, M. Hessel, V. Galanov, I.Mazura, and M.Iontseva.The concept of this article, as well as the development of practical skills in managing the processes of attracting investment resources to joint-stock companies formed on the basis of privatized enterprises; require the disclosure of the author's understanding of such methodologically important concepts as corporatism and corporation.

Corporatism is the co-ownership of the property of the corporate community or partnership, contractual relationship in meeting personal and public interests. We are in solidarity with the authors who believe that corporatism is a compromise management in order to ensure a balance of interests [3]. The ability to achieve a relative balance of interests on the basis of consensus and compromises is a distinctive feature of the corporatist model. Corporation - from the English corporation - an association, a set of persons uniting to achieve common goals, carrying out joint activities and forming an independent subject of law - a legal entity [4].

According to professors of economics C. McConnell and S. Brue, a corporation is a legal form of business that is distinct and separate from the specific individuals who own them. These government-recognized "legal entities can acquire resources, own assets, manufacture and sell products, borrow, provide loans, sue and be sued in court, and perform all those functions that are performed by any other type of enterprise. $\gg . .$.

Some researchers present corporate (joint-stock) property as a form of manifestation of private property. The rationale for this position does not go from economics to law, but, on the contrary, from the existing legislative acts and their interpretation in the legal literature 
to the economic interpretation of legal provisions. However, the legal and not the political and economic interpretation of the category "corporate property" or "collective property" [6] does not reveal its essential content as a historically defined form of appropriation of material and spiritual benefits. As a result, it is impossible to determine the place of this form of ownership in the system of property relations.

In other words, without defining the nature of the appropriation, it is impossible to separate it into a separate, independent form of ownership. The main arguments for considering corporate ownership as one of the varieties of private ownership are:

1. The existence in a market economy of the domination of capital, which determines the entire system of production relations. Consequently, "corporate property" under these conditions does not cease to be capital and the presence of collective property does not cancel the reproduction of the relationship "capital - wage labor", but only gives it certain specificity.It consists in the fact that each worker treats "like his own capitalist to himself as a wage worker" [7]. Therefore, this is the first argument, they believe, that there is no reason to represent joint stock ownership as distinct from private ownership.

2. Each member of an enterprise based on collective and joint-stock ownership acts as a private owner of a certain share of the means of production, expressed in value. In accordance with the above, collective and joint-stock ownership is nothing more than a form of manifestation of private ownership.Some economists, in particular V.P. Patrikeev and I.V.Nekrasov, they propose to classify the shared variety of collective ownership as private and joint ownership as a public form of ownership. So, arguing about two types of collective property, in particular, V.P. Patrikeev notes: "Both of these types of property are completely unsuccessfully combined under the term"collective". Under the public property of V.P. Patrikeev understands "types of property that do not have an owner ..." [8], omitting the important fact that property does not exist without an owner.

3. The most important feature, a concrete expression of the economic isolation of the producer is the presence of his own private or isolated interest. With the formation of collective property, collective interests are also formed (where the interests and aspirations of individual owners are leveled and largely mitigated), and the collective of owners is already an independent subject of production relations, isolated within the economic system [7]. Thus, they believe, collective and joint-stock ownership is also private due to the complete isolation of labor collectives from each other and from society as a whole, as a set of private producers [9].

Also, the authors cannot agree with the extremely opposite point of view of other researchers, who distinguish collective property as a special, independent one, different from both private and public forms of ownership [10]. In our opinion, the specific nature of collective and, therefore, joint-stock ownership determines their intermediate location between private and public forms of ownership in the system of property relations. As follows from the Civil Code of the Republic of Uzbekistan, the property of the corporation is created at the expense of the contributions of the founders, but, on the other hand, the society itself has the right, as a legal entity, to own the property acquired in the course of its activity. The complexity of the issue is aggravated by the fact that the acquired corporations, as a legal entity, in the course of their activities, tangible and intangible assets still belong to the founders and can be distributed by them among themselves in proportion to their contributions. At the same time, corporate managers have the right (albeit somewhat limited) to independently make decisions about the use and ownership of property, including the right of alienation. Different subjects, entering into different kinds of communities, must dialectically combine their rights, interests and duties with the rights, interests and duties of the associations they created - legal entities. First of all, we are talking about a deep discrepancy between formal property rights and real possibilities of control in corporate enterprises, which leads to numerous manifestations of ineffective 
functioning of property relations, violation of contractual rights and property rights, ineffectiveness of bankruptcy procedures, the existence of legal and semi-legal forms of property redistribution in favor of political decision makers, inefficient use of resources, etc. A number of arguments speak in favor of expanding privatization.First, privatization provides conditions for the formation of social groups materially interested in the accelerated development of market relations. Secondly, the long-term parallel existence of public and private companies inevitably gives rise to numerous price "distortions" and especially favorable conditions for counterproductive speculative transactions. Third, as you know, the weighted average price of capital of a firm decreases with an increase in gearing to a 50:50 ratio, and then begins to decline smoothly. This is due to the fact that with an increase in the level of gearing, the risk for investors increases and they, as a rule, agree to remain shareholders of the company only if they guarantee a higher yield than is offered on average in the market, and an increase in the size of dividends means an increase in the price of equity capital. Hence the idea of reducing or completely removing the state from the number of owners of joint-stock companies the sale of shares will make it possible to fully earn the domestic securities market, especially its secondary segment, due to which the performance of the JSC will be assessed using market, objective methods.

\section{Results and discussion}

Thus, the most important feature of a corporation, confirming the ambiguity of its position in the "real capital - fictitious capital" JSC wish to set up a "double funding". On the one hand, financing is carried out through amortization, retained earnings and bank loans, and on the other, through the issue and sale of securities. The first type actualizes the real financial opportunities, and the second - fictitious -in capital (this distinction is conditional, since only captures the accents). The analysis allowed the authors to identify the characteristic economic, legal and organizational features of modern corporations, the main of which are:

- separation of ownership from management functions;

- dual ( dichotomous ) nature of ownership of corporation assets;

- a complex property complex formed by the contributions of the founders and the corporation itself in the course of economic activity;

- managers and directors in corporations have legal decision-making power;

- independence as a legal entity;

- limited liability of individual investors;

- the possibility of transferring shares to other persons;

- and, most importantly, the possibility of double financing in the "real capital fictitious capital" system.

Investment assets of open joint-stock companies are the most mobile and incomparably larger than in the case of corporate enterprises with a different organizational and legal form. and shareholders, as owners, are endowed with rights, but also have interests, which, often, may not only not coincide, but also be directly opposite. This applies not only to participants, whose relationships are built on the basis of subordination and mutual control, but also within groups of participants with the same rights (large shareholders - small shareholders, shareholders, owners of ordinary shares-shareholders, owners of preferred shares, etc.) ... Here lies one of the main problems of corporate governance, which is that, without violating the rights of one of the participants, his interests may be infringed. At the same time, if the rights of a shareholder are protected by both legislation and the corresponding legal infrastructure, then the protection of the interests of the participants becomes fully a function of good corporate governance [12]. In the scientific literature, 
economic analysis is mainly carried out within the framework of traditionally established trends and views. The Organization for Economic Co-operation and Development (OECD) defines corporate governance as "the internal mechanisms through which companies are governed and controlled, [1] which implies a system of relationships between the company's management board, its board of directors, shareholders and other stakeholders. Corporate governance is the structure used to define the goals of the company and the means to achieve those goals, as well as to control this process. Good corporate governance should provide appropriate incentives for the board and managers to pursue objectives that are in the best interests of the company and shareholders. It should also facilitate effective monitoring, thus encouraging firms to use resources more efficiently "[1].For their part, the authors of the article consider it necessary to take into account the main goal of corporate governance when forming the conceptual framework, namely, to ensure the growth of the long-term value of shareholders' capital, while maintaining the balance of interests of all stakeholders. The concept of "corporate governance" is naturally associated with the concept of "corporation", however, corporate governance should not be interpreted only as the management of a corporation. Nowadays, corporate governance is considered more often in a broad sense, i.e. as management, characterized by a high level of organization and its inherent special properties. Based on the above definition of a corporation, the objects of corporate governance are:

1) the property of the founders, united in a business company or partnership (corporation); 2) tangible and intangible assets owned by the corporation and used by it for the implementation of statutory activities in order to generate income.Liberalization of economic relations and reforming the economy of Uzbekistan, the tasks of restructuring property relations and bringing domestic issuers to the world capital markets, require the development of an adequate corporate governance model for the republic. Analysis of the financial condition of the republic's enterprises shows that investment activity in the real sector of the economy is at a low level, there is no practice of attracting financial resources by issuing and placing securities, joint stock companies do not have an effective dividend policy.

The corporate governance system and the stock market are two sides of the same coin. Corporate governance increases the tradability of shares on the stock market, the stock market, especially its secondary segment, through a wide range of shareholders ensures genuine market control over the activities of the executive body of the JSC and the efficiency of the corporate governance system. The mutual influence of privatization and the stock market can be viewed from two positions. On the one hand, the stock market influences privatization, contributing to the mobilization of internal and external financial resources. Market indicators show the current state of the financial system - the size of the market, the level of liquidity, the possibility of accumulating free savings, i.e. key factors in deciding what, how and when to sell. On the other hand, the deepening of the privatization process increases the number of shares traded on the market, thereby stimulating the further development of the stock market. In countries with developed securities markets, this assessment occurs through a change in the market value of shares: the presence of an effective corporate governance system leads to an increase in the value of JSC shares and vice versa.The ownership structure of enterprises, formed as a result of the first stages of privatization in Uzbekistan, turned out to be unfavorable for the subsequent growth of the stock market and does not contribute to the restructuring of ownership relations through the securities market. This is clearly demonstrated by the analysis of trading volumes in the primary and secondary securities markets of the republic (see Fig. 1). 


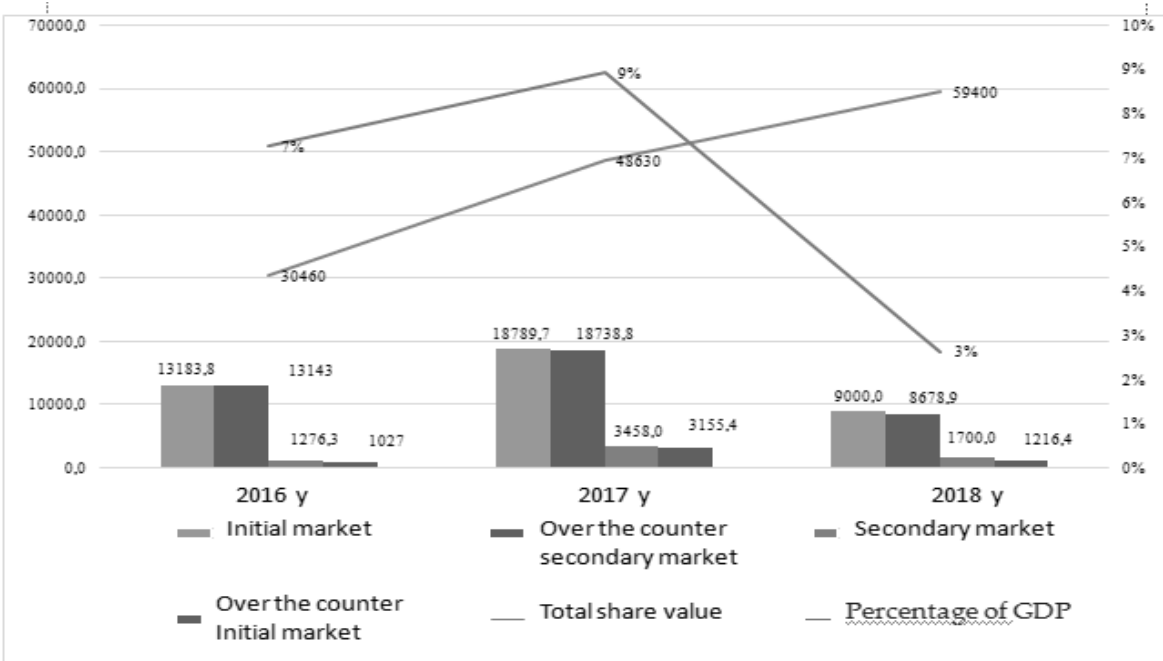

Fig. 1. Indicators of the development of the securities market of the Republic of Uzbekistan (left scale in billion soums, right scale in\%) [16]

With the volume of issued shares by 2019 almost 140 trillion soums (at par), the turnover of the primary stock market of the Republic of Uzbekistan in 2018 at market prices did not exceed 9 trillion. sum, or about 7 percent of the available resources. At the same time, the main sales of the primary market occur in the over-the-counter segment, which accounts for up to 85 percent of the turnover. The total turnover of the securities market in Uzbekistan in 2018 amounted to only 3 percent of the country's GDP. The catastrophically low capitalization of the secondary stock market is of particular concern. The problem is that the low capitalization of the secondary market (does not create conditions for truly market pricing in the securities market. Hence, doubts about the fairness of the formed prices for shares, provided for implementation in the process of transformation of state property. Therefore, any delay in the development of the national securities market will lead to a failure of the attempt to conduct an IPO of domestic JSCs, if only because one of the requirements of the world stock markets for an IPO is the regular quotation of at least $20-25 \%$ of the issuer's shares on the domestic exchange market. Noting the existence of certain deficiencies in the functioning of the domestic secondary market, we focus on the fact that without the creation of the necessary market mechanisms re allocation of capital in the most efficient production and attract investment for the development of enterprises, leading to the stagnation of the entire stock market. The reason for this is that a feature of the formation of prices in the financial market is a significant impact on this process of the speculative capital circulating on it. Hence, the role of the secondary market is high, the level of development of which is largely determined by the ability of the stock market as a whole to ensure the performance of its functions. Despite the significant legislative and infrastructural development of the stock market in Uzbekistan, it should be noted that there are practically no investment institutions that carry out collective investment, underwriting, market-maker operations that are capable of providing professional assistance to business entities in the rapid placement and quotation of securities. Today, for domestic issuers, the need for infrastructure services is due to the need to increase the investment attractiveness of the securities they issue and to generate demand for them from foreign and domestic investors. A strategic investor feels more confident in a country of which he is a non-resident, when he has the potential to realize his 
block of shares in the event of a change in market conditions, a change in the business profile, and finally returning to his homeland.

\section{Conclusions and proposals}

As a result of this structural relationship, the stock market of Uzbekistan does not yet play a full-fledged disciplining and corrective role in the corporate governance system. It is impossible to build a stock market on non-performing assets. The development of the domestic capital market is possible only with a comprehensive solution to all problems. Spot attempts to influence this market can only create the appearance of activity and further discredit (reduce investment attractiveness) the stock market of Uzbekistan, which has a huge investment potential, if only due to the fact that Uzbekistan is one of the ten world leaders in natural resources, at the same time, almost $90 \%$ of assets have not found their true owner. Based on the above, the following conclusions can be drawn:

1. Deepening the privatization processes should provide for the fulfillment of the following conditions:

a shift in emphasis from quantitative indicators of privatization to deep restructuring of industries and improvement of mechanisms for post-privatization support for enterprises; expanding the arsenal of methods and methods of privatization in order to more fully take into account industry and regional characteristics, improve the assessment of privatized property, and its sale on a tender basis; increasing the efficiency of the economy by actively supporting entrepreneurship, implementing the procedures for reorganization and restructuring, as well as liquidating unprofitable enterprises; involvement of the general public in the process of corporatization and further development of the stock market.

2. Privatization can not be considered samodos tatochnoy economic purpose, as rightly noted E. Rosenbaum, F. Bonker and X. Wagener . Instead of "fetishization" of privatization as a means of achieving political consensus it should be emphasized that the ultimate goal of economic transformation is to improve the economic well-being blah Godard increased competition and the effective division of labor. Therefore, according to E. Rosenbaum et al., The question of the cos of the market is the most important, and the role of the privatization should be assessed in the light of its contribution to the development of market institutions.

As the primary necessary steps to rectify the current state of affairs, it is considered necessary:

1. To develop and implement practical mechanisms for attracting funds from the population to the stock market. At the same time, to solve this problem "from above", by initiating separate IPOs and SPOs is to create the appearance of public activity in the capital market ... Moreover, the most difficult and important thing in this process is not underwriting support, market-maker support, road shows, etc., but systematic work carried out with shareholders after the sale of shares. If there is no such work, then, as a rule, this leads to a negative result, since it discredits the IPO and SPO. Suffice it to say that lack of knowledge or unwillingness to use such an effective corporate governance tool as dividend policy leads to a deterioration in the market position of shares. A small shareholder, especially in our country, where the secondary market is not developed and there is no system of quotations for the growth of the share price, sees only one source of return on shares - dividends.

2. A promising direction for attracting financial resources from the securities market should be the active functioning of the initial public offering (IPO) and secondary public offering (SPO) on the domestic market, which will increase liquidity and increase the share of free float shares. The development of mechanisms and procedures for an internal IPO will allow a step-by-step transition to the organization and development of sales of 
securities of domestic issuers in foreign countries. In this regard, it is advisable to develop and adopt a special concept for the output of domestic securities to international capital markets, which in the long and short term would provide for:1) measures for the selection of issuers of Uzbekistan, with a well-oiled system of corporate governance, whose shares could be quoted on international stock markets;2) government support for selected domestic issuers, whose securities, ultimately, would circulate on foreign stock markets;3) measures to improve domestic legislation, ensuring the creation of conditions for the issue and circulation of national securities in the securities markets of near and far abroad;4) adaptation of domestic standards for accounting and financial reporting of joint stock companies to international requirements;5) organization of work through foreign economic departments and with the use of representative offices of international organizations for the preparation and conclusion of interstate (bilateral or multilateral) agreements on the possibility of placing domestic securities in the relevant countries and securities of foreign states in our country;6) consultations and negotiations with foreign banks regarding the possibility of placing domestic shares through depositary receipts. At the same time, it is necessary to analyze the mistakes made in the preparation of previous documents, the implementation of which ended in failure, draw the appropriate conclusions, outline a new action plan, taking into account the mistakes of past years and the experience of neighbors from neighboring countries.

\section{References}

1. OECD Principles of Corporate Governance, https ://www.oecd.org/

2. A. Begmatov, M. Khamidulin, M. Butaboev, Corporate culture and corporate governance, 224 (2007)

3. F. M. Rusinov, E. V. Popova, The theory of corporate governance in an unstable state of the economy, 60 (1999)

4. I. I. Mazur, V. D. Shapiro, N. G. Olderogge, Corporate Management: Handbook for Professionals, 36 (2003)

5. K. R. Mc Connell, S.L. Brue, Economics: principles, problems and politics, 74 (2002)

6. R. G. Emtsov, M. Yu. Lukin, Microeconomics, 172 (1997)

7. A. Zolotayev, Russian economic journal, 7, 53 (1997)

8. V. P. Patrikeev, Economics of Construction, 2, 5 (1993)

9. A. Melentiev, Russian economic journal, 3, 73 (1993)

10. H. Kurbanov, Corporate finance, Study guide (2005)

11. D. M. Skirdko, Corporate governance in the real estate market: Dis. Cand. economy. Sciences, 13 (2004)

12. Law of the Republic of Uzbekistan "On property in the Republic of Uzbekistan", 8

13. Manual on corporate governance, 1(1), 28 (2004)

14. S. P. Kukura, The theory of corporate governance, 121 (2004)

15. S.Lyapunov, Problems of theory and practice of management, 6, 24 (2001)

16. Data of the State Statistics Committee of the Republic of Uzbekistan 